\title{
Comparison of conventional and rapid methods for determination of total aerobic mesophilic microorganisms and Enterobacteriaceae in poultry products
}

\section{Kanatlı eti ürünlerinde toplam aerobik mezofilik mikroorganizma ve Enterobacteriaceae belirlenmesinde klasik ve hızlı yöntemlerin karşılaștırması}

\author{
Çetin ERTUĞRUL', ibrahim ÇAKIR²
}

\section{ABSTRACT}

Objective: In this study, it was aimed to compare the conventional and rapid test methods in determining the numbers of both total aerobic mesophilic microorganizm and Enterobacteriaceae in totally 123 poultry products which were both whole carcass and mechanically separated.

Methods: In In the study, it was simultaneously used ISO 4833:2003 conventional method and TEMPO TVC rapid test method for determining the number of total aerobic mesophilic microorganism, as well as ISO 21528-2:2004 conventional method and TEMPO EB rapid test method for the enumeration of Enterobacteriaceae. According to this, it was statistically evaluated the results belonging to 100 samples in a total of aerobic mesophilic microorganism count and also 85 samples in Enterobacteriaceae count. Descriptive statistical test and F-test were performed by using office excel 2007 Software (Microsoft, Redmond, USA) at the statistical comparison of the conventional and rapid test methods. In addition, linear regression and Pearson correlation analyses were performed by using MINITAB 16 software (Minitab Inc., State College, TX, USA).

\section{ÖZET}

Amaç: Bu çalıșmada, bütün karkas ve mekanik olarak ayrılmıș 123 adet kanatlı et ürününde, toplam aerobik mezofilik mikroorganizma sayısı ve Enterobacteriaceae sayısının belirlenmesinde klasik ve hızlı test yöntemlerinin karșılaștırılması amaçlanmıștır.

Yöntemler: Çalıșmada, toplam aerobik mezofilik mikroorganizma sayısının belirlenmesinde "ISO 4833: 2003” klasik yöntemi ve “TEMPO TVC" hızlı test yöntemi, Enterobacteriaceae sayısının belirlenmesinde ise "ISO 21528-2: 2004" klasik yöntemi ve "TEMPO EB" hızlı test yöntemi eș zamanlı olarak çalıșılmıștır. Buna göre, toplam aerobik mezofilik mikroorganizma sayımında 100, Enterobacteriaceae sayımında ise 85 örneğe ait sonuçlar istatistikî olarak değerlendirilmiștir. Klasik ve hızlı test yöntemlerinin istatistiki olarak karșılaștırılmasında office excel 2007 (Microsoft, Redmond, ABD) programı kullanılarak, tanımlayıcı istatistik testleri ve F-testi yapılmıștır. Lineer regresyon ve Pearson korelasyon analizleri ise MINITAB 16 programı (Minitab Inc., State College, TX, ABD) kullanılarak yapılmıștır.

'Bolu Food Control Laboratory Directorate, Bolu, Turkey

${ }^{2}$ Abant İzzet Baysal University, Faculty of Engineering and Architecture, Department of Food Engineering, Bolu, Turkey

İletişim/ Corresponding Author : İbrahim ÇAKIR

Abant İzet Baysal University, Faculty of Engineering and Architecture, Department of Food Engineering, Gölköy

14280 Bolu, Turkey Tel : +905358989658 E-posta/E-mail : ibrahimcakir@ibu.edu.tr

Geliş Tarihi / Received : 27.12.2015 Kabul Tarihi / Accepted : 30.06 .2016

DOI ID : 10.5505/TurkHijyen.2016.98470

Ertugrul Ç, Çakır i. Comparison of conventional and rapid methods for determination of total aerobic mesophilic microorganisms and Enterobacteriaceae in poultry products. Turk Hij Den Biyol Derg, 2016; 73(4): 379-388 
Results: According to the results of the study, it was determined that there was no statistically significant difference between the conventional ISO 4833:2003 and TEMPO TVC methods with respect the accuracy of total aerobic mesophilic bacteria count results. Similarly, it was found that there was also no statistically significant difference between the conventional ISO 21528-2:2004 and TEMPO EB methods in terms of the accuracy of Enterobacteriaceae count results.

Conclusion: It was concluded that microbiological analysis performed by TEMPO rapid test system is more advantageous, because it is significantly decreased duration of analysis, analysis cost, ease of operation and risk of contamination according to the conventional ISO methods both the number of total aerobic mesophilic microorganism and Enterobacteriaceae counts.

Key Words: poultry, Enterobacteriaceae, total aerobic mesophilic microroganism, microbiological techniques.
Bulgular: Çalıșmanın sonuçlarına göre toplam aerobik mezofilik bakteri sayım sonuçlarının doğruluğu açısından klasik ISO 4833: 2003 ve TEMPO TVC yöntemleri arasında istatistiki olarak bir farkın bulunmadığı belirlenmiștir. Aynı șekilde, Enterobacteriaceae sayım sonuçlarının doğruluğu açısından klasik ISO 21528-2: 2004 ve TEMPO EB yöntemleri arasında da istatistiki olarak bir farkın bulunmadığı tespit edilmiștir.

Sonuç: Gerek toplam aerobik mezofilik mikroorganizma, gerekse Enterobacteriaceae sayımlarında klasik ISO yöntemlerine göre, analiz süresi, analiz maliyeti, çalıșma kolaylığı ve kontaminasyon riskinin önemli oranda düșük olması nedeniyle TEMPO hızlı test sistemi ile yapılan mikrobiyolojik analizlerin daha avantajlı olduğu sonucuna varılmıștır.

Anahtar Kelimeler: kanatı eti, Enterobacteriaceae, toplam aerobik mezofilik mikroorganizma, mikrobiyolojik teknikler.

\section{INTRODUCTION}

Increased production and consumption of poultry products concordantly give rise to increased measures in food safety within this industry (1). This is because a majority of the cases involved in food infection and intoxication worldwide originates from poultry (2). According to the report published by $\mathrm{FAO} / \mathrm{WHO}$ in 2002 (3), it was indicated that 26\% of food borne epidemic diseases were due to poultry and products.

Detection of presence or a higher level of an indicator microorganism from predefined values suggests that the relevant product is produced under such conditions that can be contaminated by pathogenic and toxigenic microorganisms (4). Several microorganisms can be used as an indicator of hygiene in poultry. More specifically, the enumeration of total aerobic mesophilic microorganism has a particular importance due to offering a more coverage of microorganisms as well as providing a general insight of hygiene about products (5).

The Enterobacteriaceae family includes many kinds of bacteria containing coliform bacteria, fecal coliforms, Escherichia coli, etc. as well as Proteus spp., Salmonella spp., and Aeromonas spp. Therefore, a close relation is found between the total counts of Enterobacteriaceae and fecal contamination. Thanks to the analyses involving Enterobacteriaceae and coliform bacteria, it becomes possible to make 
an assessment on whether a food is produced under hygiene conditions or not (6).

Microbiological analysis methods can be categorized into conventional and rapid methods. Rapid detection of microbiological risk factors is important in terms of both ensuring quality assurance and protecting the public health in the food industry. For this reason, several alternative methods were developed in order to shorten the duration of analysis in food microbiology (7). Many samples can be examined in a shorter time by means of numerous automatic analysis systems, one of which is called TEMPO system, developed by bioMérieux (8). TEMPO is an automated system based on the most probable number (MPN) technique, equipped with filling, and reading units in order to detect the microorganisms used as the quality indicator. In this system, analysis can be performed by using a card comprising a total of 48 wells across three different dilution levels (9).

In this study, we aim to compare the conventional ISO methods and TEMPO rapid test methods for determining the enumeration of total aerobic mesophilic bacteria (TAMB) and Enterobacteriaceae in naturally contaminated poultry products.

\section{MATERIALS AND METHODS}

\section{Sample Preparation}

A total of 123 samples of raw poultry products either supplied as whole carcass or mechanically separated were collected from different retail markets in Bolu province of Turkey in 2011-2012, and were immediately transported in insulated cooler boxes to the laboratory, Bolu Food Control Laboratory Directorate. Samples were stored at $4^{\circ} \mathrm{C}$ until analysis. Naturally contaminated samples included: whole raw chicken (38), whole chicken legs (14), breast fillets (12), whole chicken wings (11), drumsticks (10), chicken thigh cutlets (10), chicken leg quarters (7), chicken cutlets (6), chicken tenderloin (5), chicken thigh cutlets with skin (5) and deboned turkey cutlets (5). The samples arrived under cold-chain were subjected to analysis without any delay using the conventional ISO 4833 method (10) and TEMPO TVC (Total Viable Count) rapid test method (11) for determining the enumeration of TAMB, and the conventional ISO 21528-2 method (12) and TEMPO EB (Enterobacteriaceae) rapid test method (13) for determining the enumeration of Enterobacteriaceae in microbiology laboratory.

\section{Homogenization of samples}

A sample of $10 \mathrm{~g}$ from poultry was placed into a homogenizer bag with filter (stomacher bag) under sterile conditions and $90 \mathrm{~mL}$ of buffered peptone water was added into the bag, yielding a dilution ratio of $1 / 10$. It was then homogenized for two minutes using stomacher (AES Chemunex, France), thus making an initial suspension ready. From the initial suspension, a series of dilutions $(10-2,10-3)$ were prepared using tubes each containing $9 \mathrm{~mL}$ Ringer solution (Merck, Germany).

\section{Enumeration of TAMB by conventional methods}

TAMB count was performed according to procedures described in standard ISO procedure numbered ISO 4833:2003 Horizontal method for the enumeration of microorganisms (Colony-Count Technique at $\left.30^{\circ} \mathrm{C}\right)(10)$.

\section{Enumeration of TAMB by TEMPO TVC}

$3 \mathrm{~mL}$ of distilled sterile water was added into the lyophilized TEMPO TVC medium (bioMérieux, France), and the mixture was blended by vortex (IKA, Germany) to allow the medium dissolved. One $\mathrm{mL}$ of initial suspension with a dilution rate of 10-1 was added into the medium ready for inoculation. 
All the medium inoculated $(4 \mathrm{~mL})$ was filled into TEMPO TVC test cards using TEMPO filler entity. When completed the filling process, the cards were placed to incubation racks to perform the incubation process at a temperature of $30 \pm 1^{\circ} \mathrm{C}$ for about $40-48$ hours. At the end of the incubation, the cards were read by TEMPO reader system and the results were recorded. During this operation, the reader above scans the barcode of each card and interprets the fluorescent radiation occurred in the wells. Hence, it automatically matches the name of the sample with type of the test, dilution rate and the resulting count, followed by screening the results (11).

\section{Enumeration of Enterobacteriaceae by conventional methods}

Enterobacteriaceae counting was performed according to procedures described in standard ISO procedure numbered ISO 21528-2:2004-Horizontal method for the detection and enumeration of Enterobacteriaceae - Chapter 2: Colony-Count Technique (12).

\section{Enumeration of Enterobacteriaceae by TEMPO EB}

Three $\mathrm{mL}$ of distilled sterile water was added into the lyophilized TEMPO EB medium (bioMérieux, France), and the mixture was blended by vortex (IKA, Germany) to allow the medium dissolved. One $\mathrm{mL}$ of initial suspension with a dilution rate of 10-1 was added into the medium ready for inoculation. All the medium inoculated $(4 \mathrm{~mL})$ was filled into TEMPO EB test cards by using TEMPO filler entity. When completed the filling process, the cards were placed to incubation racks to perform the incubation process at a temperature of $35 \pm 1{ }^{\circ} \mathrm{C}$ about $22-27$ hours. At the end of the incubation, the cards were read by TEMPO Reader system and the results were recorded (13).

\section{Statistical analyses}

A statistical comparison was performed between the log counts from TAMB and Enterobacteriaceae by using both methods. During statistical calculations, MS Office Excel (Microsoft, USA) was used for performing descriptive statistical tests (Anderson Darling Test) and F-test, whereas Minitab 16 (Minitab Inc. USA) was used for linear regression analysis and Pearson correlation analyses.

\section{RESULTS}

Since the results of 23 and 38 samples out of 123 samples analyzed were not within the identifiable range (lower; not found $<10 \mathrm{cfu} / \mathrm{g}$ or more; $>4.9 \times 104,5,6 \mathrm{cfu} / \mathrm{g})$ in detecting and enumerating the total aerobic mesophilic microorganisms and Enterobacteriaceae respectively; they were not taken into account of statistical calculations.

The results from the enumeration of total aerobic mesophilic microorganisms based on both methods given in Table 1.

Regarding the descriptive statistical results, a slight difference of $0.02 \mathrm{log} \mathrm{cfu} / \mathrm{g}$ was observed between the average values, and the standard errors related to the values obtained based on both methods in the analysis of total aerobic mesophilic microorganisms counts.

F-test was performed in order to determine whether there is any difference between the variance of the results obtained. The test results are shown in Table 1. As the critical value of twotailed $\mathrm{F}$ test (1.49) was more than $\mathrm{F}$ value (1.05), no statistically significant difference was found with a probability of $95 \%$ between the variances $(0.64$ and 0.61 ) obtained from the analyses by using both methods. As a result of Pearson correlation analysis, the coefficient of Pearson correlation between ISO 4833:2003 and TEMPO TVC methods were found to be 0.813 . The results from analyses with correlation 
Table 1. The number of samples used in the statistical comparison of TAMB between ISO and TEMPO TVC methods and descriptive statistical results

\begin{tabular}{|c|c|c|c|c|}
\hline \multirow{2}{*}{ Sample } & \multirow{2}{*}{$\begin{array}{c}\text { Number of } \\
\text { samples } \\
\text { analyzed }\end{array}$} & \multirow{2}{*}{$\begin{array}{c}\text { Number of } \\
\text { data evaluated }\end{array}$} & \multicolumn{2}{|c|}{$\begin{array}{l}\text { Mean values of results } \\
(\log \mathrm{cfu} / \mathrm{g})\end{array}$} \\
\hline & & & ISO 4833 & TEMPO TVC \\
\hline Whole raw chicken & 38 & 35 & $4.03 \pm 0.86$ & $4.02 \pm 0.83$ \\
\hline Whole chicken legs & 14 & 13 & $3.66 \pm 0.56$ & $3.70 \pm 0.84$ \\
\hline Chicken breast fillets & 12 & 11 & $4.04 \pm 1.13$ & $4.19 \pm 0.81$ \\
\hline Whole chicken wings & 11 & 2 & $4.90 \pm 0.20$ & $5.07 \pm 0.46$ \\
\hline Chicken drumsticks & 10 & 10 & $4.29 \pm 0.29$ & $4.12 \pm 0.69$ \\
\hline Chicken thigh cutlets & 10 & 4 & $4.10 \pm 0.67$ & $4.27 \pm 0.50$ \\
\hline Chicken leg quarters & 7 & 6 & $4.28 \pm 0.26$ & $4.18 \pm 0.27$ \\
\hline Chicken cutlets & 6 & 4 & $3.28 \pm 1.09$ & $3.30 \pm 1.37$ \\
\hline Deboned turkey cutlets & 5 & 5 & $3.74 \pm 0.51$ & $3.69 \pm 0.82$ \\
\hline Chicken tenderloin & 5 & 5 & $3.14 \pm 0.28$ & $3.28 \pm 0.30$ \\
\hline Chicken thigh cutlets with skin & 5 & 5 & $3.98 \pm 0.22$ & $4.10 \pm 0.39$ \\
\hline \multirow[t]{7}{*}{ Total } & 123 & 100 & & \\
\hline & \multicolumn{4}{|c|}{ Descriptive statistical results } \\
\hline & & Mean & 3.95 & 3.97 \\
\hline & & Standard deviation & 0.78 & 0.80 \\
\hline & & Variance & 0.61 & 0.64 \\
\hline & Num & $r$ of data evaluated & 100 & 100 \\
\hline & & fidence level (95\%) & 0.15 & 0.16 \\
\hline \multicolumn{5}{|c|}{ F-test for two methods regarding the variance } \\
\hline & & Observation & 100.00 & 100.00 \\
\hline & & Df & 99.00 & 99.00 \\
\hline & & $\mathrm{F}$ & 1.05 & \\
\hline & & critical two-tailed & 1.49 & \\
\hline
\end{tabular}


coefficient ranging from 0.75 to 1.00 indicated a high correlation between these groups compared (14). Accordingly, it is obvious that the results obtained from both methods are consistent. The following equations are deduced from the results of linear regression analysis:

$$
\log _{10} \text { TEMPO TVC }=0,6768+0,8326150
$$
4833:2003 $\log _{10}$ (Figure 1).

The results of Enterobacteriaceae count from samples are given in Table 2 according to the analyses based on both methods.

Referring to the descriptive statistical results shown in Table 2, when compared the mean values obtained from both methods, the mean value of TEMPO EB method was higher than that of ISO 21528-
2:2004 method. A difference of $0.45 \log \mathrm{cfu} / \mathrm{g}$ was also observed between the mean values of both methods, with the standard deviation and variance being the same. As a result of Pearson correlation analysis, the coefficient of Pearson correlation between ISO 21528-2:2004, and TEMPO EB methods were found to be 0.822 . The results from analyses with correlation coefficient ranging from 0.75 to 1.00 indicated a high correlation between these groups compared (15). Accordingly, it is obvious that the results obtained from both methods are highly consistent. The linear regression analysis yielded the following equation:

$$
\log _{10} \text { TEMPO EB }=0,7876+0,830315021528-
$$
2:2004log $\log _{10}$ (Figure 2).

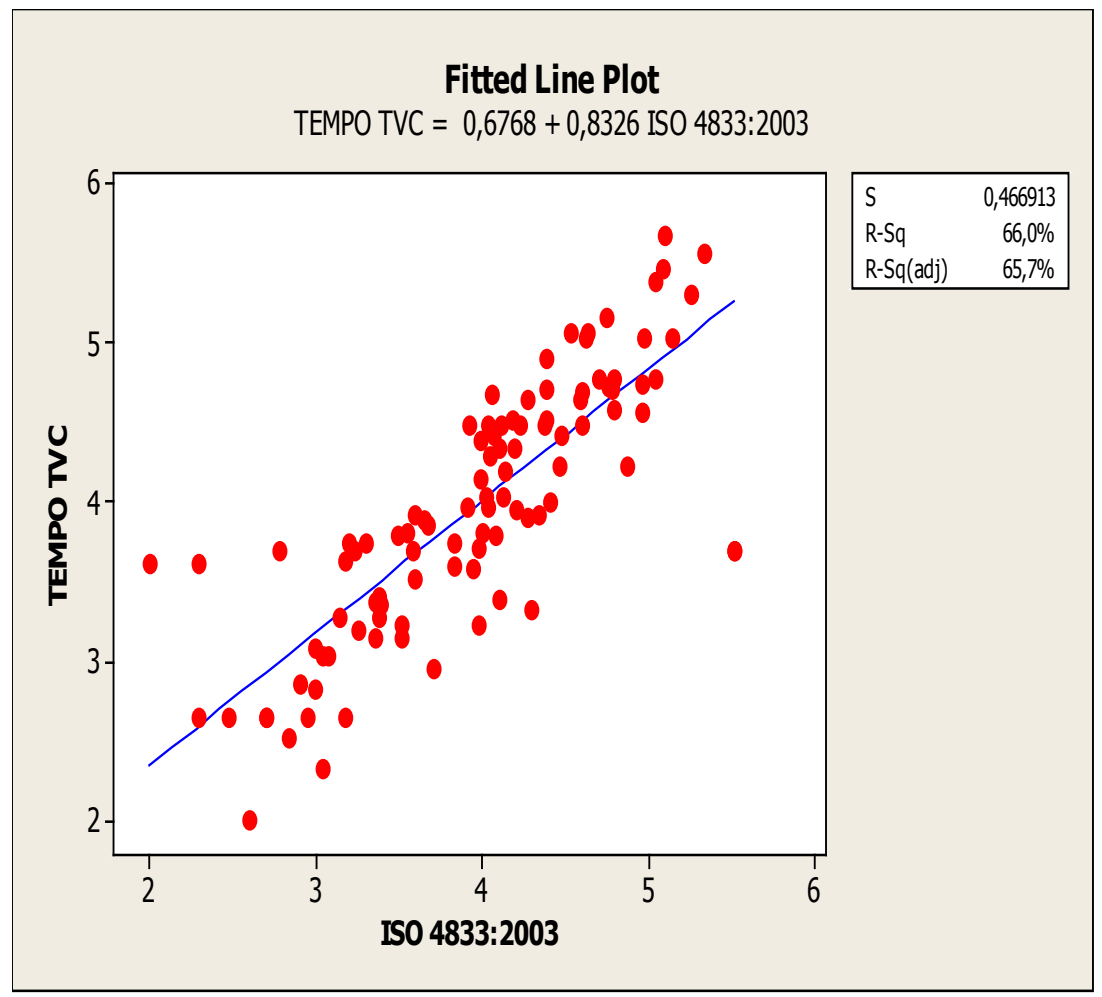

Figure 1. Linear regression of TEMPO TVC versus ISO 4833 
Table 2. The number of samples used in the statistical comparison of Enterobacteriaceae counts between ISO 21528-2 and TEMPO EB methods and descriptive statistical results

\begin{tabular}{|c|c|c|c|c|}
\hline \multirow{2}{*}{ Sample } & \multirow{2}{*}{$\begin{array}{c}\text { Number of } \\
\text { samples } \\
\text { analyzed }\end{array}$} & \multirow{2}{*}{$\begin{array}{c}\text { Number of } \\
\text { data evaluated }\end{array}$} & \multicolumn{2}{|c|}{$\begin{array}{l}\text { Mean values of results } \\
(\log \mathrm{cfu} / \mathrm{g})\end{array}$} \\
\hline & & & ISO $21528-2$ & TEMPO EB \\
\hline Whole raw chicken & 38 & 26 & $4.03 \pm 0.86$ & $4.02 \pm 0.83$ \\
\hline Whole chicken legs & 14 & 7 & $3.66 \pm 0.56$ & $3.70 \pm 0.84$ \\
\hline Chicken breast fillets & 12 & 11 & $4.04 \pm 1.13$ & $4.19 \pm 0.81$ \\
\hline Whole chicken wings & 11 & 5 & $4.90 \pm 0.20$ & $5.07 \pm 0.46$ \\
\hline Chicken drumsticks & 10 & 8 & $4.29 \pm 0.29$ & $4.12 \pm 0.69$ \\
\hline Chicken thigh cutlets & 10 & 4 & $4.10 \pm 0.67$ & $4.27 \pm 0.50$ \\
\hline Chicken leg quarters & 7 & 7 & $4.28 \pm 0.26$ & $4.18 \pm 0.27$ \\
\hline Chicken cutlets & 6 & 3 & $3.28 \pm 1.09$ & $3.30 \pm 1.37$ \\
\hline Deboned turkey cutlets & 5 & 5 & $3.74 \pm 0.51$ & $3.69 \pm 0.82$ \\
\hline Chicken tenderloin & 5 & 5 & $3.14 \pm 0.28$ & $3.28 \pm 0.30$ \\
\hline Chicken thigh cutlets with skin & 5 & 4 & $3.98 \pm 0.22$ & $4.10 \pm 0.39$ \\
\hline \multirow[t]{7}{*}{ Total } & 123 & 85 & & \\
\hline & \multicolumn{4}{|c|}{ Descriptive statistical results } \\
\hline & & Mean & 1.98 & 2.43 \\
\hline & & Standard deviation & 0.68 & 0.68 \\
\hline & & Variance & 0.46 & 0.46 \\
\hline & Num & of data evaluated & 85.00 & 85.00 \\
\hline & & fidence level (95\%) & 0.15 & 0.15 \\
\hline \multicolumn{5}{|c|}{ F-test for two methods regarding the variance } \\
\hline & & Observation & 85.00 & 85.00 \\
\hline & & Df & 84.00 & 84.00 \\
\hline & & $\mathrm{F}$ & 1.02 & \\
\hline & & critical two-tailed & 1.54 & \\
\hline
\end{tabular}




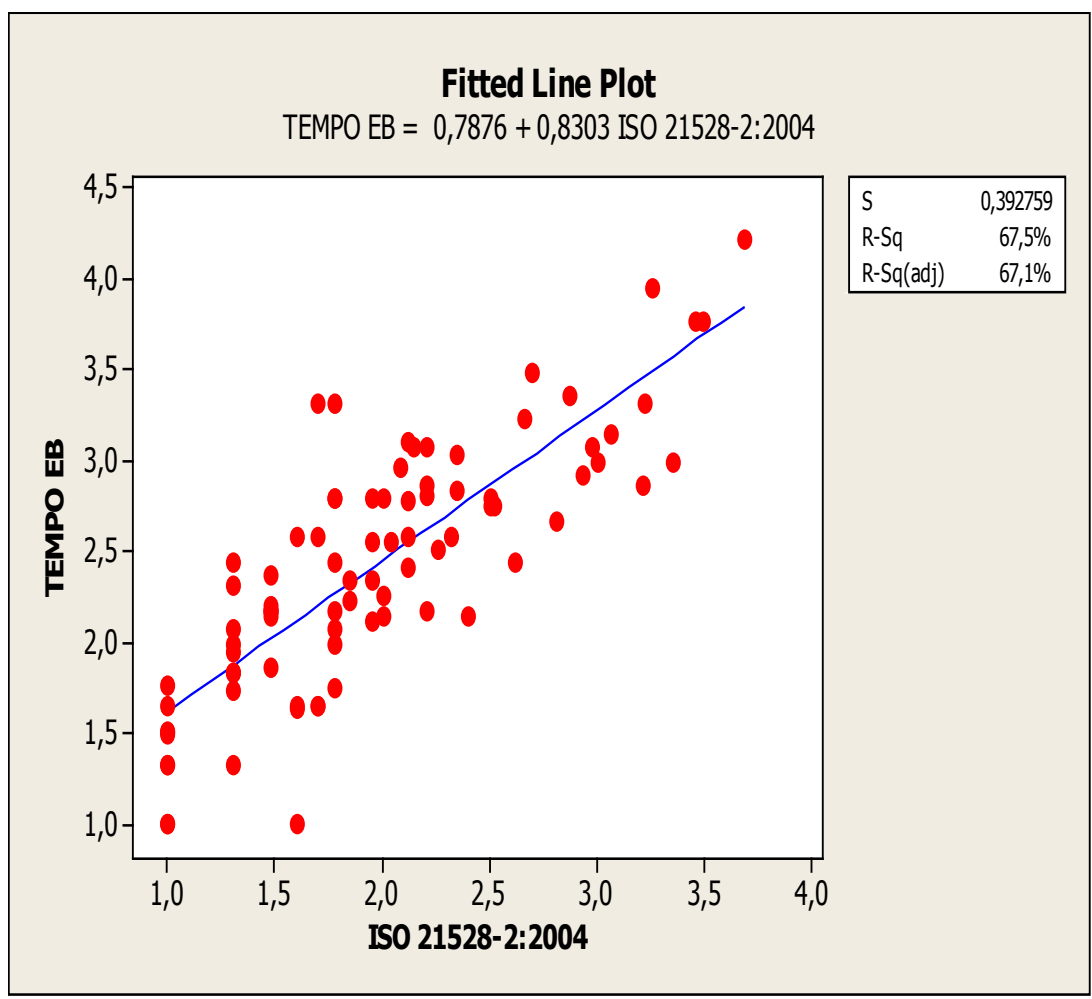

Figure 2. Linear regression of TEMPO EB versus ISO 21528

\section{DISCUSSION}

The mean values of samples analyzed according to TEMPO TVC and the conventional ISO 4833:2003 methods were found to be $3.97 \mathrm{log} \mathrm{cfu} / \mathrm{g}$ and $3.95 \mathrm{log}$ $\mathrm{cfu} / \mathrm{g}$ respectively. In a study conducted by Line et al. (15), a number of 120 samples of chicken raw carcass from production line before, and after freezing process were analyzed by using TEMPO TVC and the conventional microbial colony enumeration methods. It was found that the mean values obtained by both methods were $3.09 \log \mathrm{cfu} / \mathrm{g}$ and $3.02 \mathrm{log} \mathrm{cfu} / \mathrm{g}$ before freezing, whereas they were $1.53 \mathrm{log} \mathrm{cfu} / \mathrm{g}$ and 1.31 log cfu/g after freezing, respectively.

Linear regression and Pearson correlation analyses were performed in order to measure the compliance levels of both methods. In a study conducted by
Line et al (15) involving a number of 120 samples of chicken raw carcass from production line before and after freezing process, the carcass samples before freezing were analyzed according to TEMPO TVC and the conventional microbial colony count methods, and a high correlation coefficient of 0.972 was found. However, when using the samples after freezing, the correlation coefficient was found to be 0.710 between TEMPO TVC and the conventional rapid test methods.

Paulsen et al., (16) suggested in their study involving the analysis of a number of 180 naturally contaminated mince samples as well as samples from carcass surfaces that there was a high correlation coefficient of 0.99 between TEMPO TVC rapid test method and the conventional colony count technique. 
In a study of raw meat and mince, in order to determine the number of TAMB, both the TEMPO system and German official method were used, and the results were compared. A high correlation coefficient of 0.975 was found between the results from both methods (17).

In a study conducted by Paulsen et al., (18) involving the analysis of a number of 190 samples from naturally contaminated food in terms of Enterobacteriaceae count, the mean \pm standard deviation was calculated as $2.540 \pm 1.026 \log \mathrm{cfu} / \mathrm{g}$ by using the conventional ISO 21528-2:2004 method, whereas it was found to be $2.456 \pm 1.014 \mathrm{log} \mathrm{cfu} / \mathrm{g}$ by using TEMPO EB rapid test method. Linear regression and Pearson correlation analyses were performed in order to measure the compliance levels of both methods.

In one study conducted by Katase and Tsumura (19), involving a number of 171 samples of artificially contaminated processed soy products for determining the count of Enterobacteriaceae, they found a higher correlation coefficient than 0.98 between TEMPO EB and ISO 21528-2:2004 methods, suggesting also a higher value as compared to our result (19).

In a study involving a linear regression analysis of a number of 47 samples using TEMPO EB and ISO 215282:2004 methods, Owen et al., (6) found a correlation coefficient of 0.75 between both methods, suggesting a lower value as compared to our result.

In their study, Paulsen et al., (20) used both the conventional ISO and TEMPO rapid test methods together in order to determine the number of Enterobacteriaceae in 98 various food samples. However, we tested a lower degree of $30^{\circ} \mathrm{C}$ as incubation temperature in this study instead of $35^{\circ} \mathrm{C}$ and $37^{\circ} \mathrm{C}$ as recommended by the above methods. Accordingly, the results obtained at $30^{\circ} \mathrm{C}$ were found to be higher than those performed at $37^{\circ} \mathrm{C}$ and $35^{\circ} \mathrm{C}$ using ISO and TEMPO methods, respectively.
In conclusion, considering the results of enumeration obtained from this study as well as the statistical evaluations, no statistically significant difference was found between the results obtained by the TEMPO rapid test method and the conventional ISO test method in terms of TAMB and Enterobacteriaceae counts in poultry. However, the TEMPO rapid test method has the following advantages over the conventional ISO method:

In the detection of TAMB counts, the TEMPO TVC culture medium yielded results after 40-48 hours, whereas the conventional ISO 4833:2003 method produced results only after $48-72$ hours. Therefore, it makes a significant advantage especially in food plants as the analysis results can be determined one day earlier by using TEMPO system.

As to the detection of Enterobacteriaceae count, although both the TEMPO EB culture medium and ISO 21528-2:2004 yielded negative results after 24 hours, positive results could be provided again after 24 hours by TEMPO EB system while the conventional ISO method could yield only after 72 hours for verification. Therefore, the TEMPO EB system is suggested to be more advantageous in the sense of time.

The results from TEMPO system are by no means subjected to any verification and thus, they are considered to be absolute results. However, verification should be done by conventional ISO method, which increases the cost due to increased time and consumable material quantity, resulting in an increased labor.

As the culture medium is in the form of liquid in TEMPO system, the better growth of weak bacteria under stress and thus the more accurate result can be achieved. Particularly for the laboratories with an excessive number of daily samples and routine microbiological analyses, TEMPO rapid test system is considered to having the advantage over the conventional method. 


\section{REFERENCES}

1. Yücel Baydur A. İstanbul'da satıșa sunulan tavuk etlerinin hijyenik kalitesi üzerine araștırmalar. Yüksek Lisans Tezi, İstanbul Üniversitesi, Besin Hijyeni ve Teknolojisi Bölümü, 2006.

2. İșeri Ö, Erol i. Hindi etinden kaynaklanan bașlıca bakteriyel infeksiyon ve intoksikasyonlar. Ankara Üniv Vet Fak Derg, 2009; 56: 47-54.

3. Sezen AG. Piyasada satıșa sunulan taze kanatlı et preparatlarının son kullanma tarihlerinde duyusal ve mikrobiyolojik kaliteleri. Doktora Tezi, İstanbul Üniversitesi, Sağlık Bilimleri Enstitüsü, 2007.

4. Montville TJ, Matthews KR. Food microbiology: an introduction. Washington DC: ASM Press, 2008.

5. Halkman HBD, Halkman AK. Indicator organisms. In: Batt CA, Tortorello ML, eds. Encyclopedia of Food Microbiology. Vol 2. 2nd ed. London: Elsevier Ltd, Academic Press, 2014: 358-63.

6. Owen M, Willis C. Lamph D. Evaluation of the TEMPO most probable number technique for the enumeration of Enterobacteriaceae in food and dairy products. J Appl Microbiol, 2010; 109, 1810-6.

7. TorlakE. GidamikrobiyolojisindeEnterobacteriaceae üyeleri için kromojenik ve florojenik besiyerleri. Türk Hij Den Biyol Derg, 2011; 68 (1): 49-58.

8. Lakicevic E, Velebit B, Borovic B, Janković V, Spirić $\mathrm{D}$, Matekalo-Sverak V, et al. TEMPO ${ }^{\circ}$ most probable number technique for the enumeration yeasts and molds in feed and food products. Biotechnology in Animal Husbandry, 2011; 27(3): 1329-35.

9. Anonymous. TEMPO EB Test Procedure, https:// techlib.biomerieux.com/wcm/techlib/techlib/ storyboard/welcome/welcome.jsp, Accessed: 03.05.2012.

10. Anonymous. ISO 4833:2003 - Microbiology of food and animal feeding stuffs - horizontal method for the enumeration of microorganisms - Colonycount technique at $30{ }^{\circ} \mathrm{C}$. Geneva: International Standardization for Organization, 2003.

11. Anonymous. TEMPO TVC (Total Viable Count) Ref 80 007. bio-Me' rieux, Marcy-l'Etoile, France, 2009.
12. Anonymous. ISO 21528-2:2004 - Microbiology of food and animal feeding stuffs - Horizontal methods for the detection and enumeration of Enterobacteriaceae - Part 2: Colony-count method. Geneva: International Standardization for Organization, 2004.

13. Anonymous. TEMPO EB (Enterobacteriaceae), Ref 80003. Bio-Me'rieux, Marcy-l'Etoile, France, 2010.

14. Altınışık M. http://www.mustafaaltinisik.org uk/45-uzm-09.pdf, Accessed: 03.05.2012.

15. Line JE, Stern NJ, Oakley BB, Seal BS. Comparison of an automated most-probable-number technique with traditional plating methods for estimating populations of total aerobes, coliforms, and Escherichia coli associated with freshly processed broiler chickens. J Food Protec, 2011; 74 (9): 155863.

16. Paulsen P, Schopf E, Smulders FJM. Enumeration of total aerobic bacteria and Escherichia coli in minced meat and on carcass surface samples with an automated most-probable-number method compared with colony count protocols. J Food Protect, 2006; 69 (10): 2500-3.

17. Mahler C, Stolle A. Automated cell count via Tempo ${ }^{\circledR}$ system for more efficient routine examinations in food microbiology laboratories. Fleischwirtschaft, 2006; 86 (6): 98-100.

18. Paulsen P, Schopf E, Fuga L, Smulders FJM. Enumeration of Enterobacteriaceae in food stuffs: effect of incubation temperatures of $30{ }^{\circ} \mathrm{C}$ as compared to $35 / 37^{\circ} \mathrm{C}$. Arc Lebensmittel Hyg, 2008; 59: $192-6$.

19. Katase $M$, Tsumura K. Enumeration of microorganisms in processed soy products with an automated most probable number method compared with standard plate method. Lett Appl Microbiol, 2011; 53: 539-45.

20. Paulsen P, Borgetti C, Schopf E, Smulders FJM. Enumeration of Enterobacteriaceae in various foods with a new automated most-probable-number method compared with petrifilm and International Organization for Standardization Procedures. J Food Protect, 2008; 71 (2): 376-9. 